\title{
Front Matter: Volume 6847
}

, "Front Matter: Volume 6847," Proc. SPIE 6847, Coherence Domain Optical Methods and Optical Coherence Tomography in Biomedicine XII, 684701 (7 March 2008); doi: 10.1117/12.792112

SPIE. Event: SPIE BiOS, 2008, San Jose, California, United States 


\section{Coherence Domain Optical Methods and Optical Coherence Tomography in Biomedicine XII}

Joseph A. Izatt

James G. Fujimoto

Valery V. Tuchin

Editors

21-23 January 2008

San Jose, California, USA

Sponsored and Published by

SPIE

Volume 6847

Proceedings of SPIE, 1605-7422, v. 6847

SPIE is an international society advancing an interdisciplinary approach to the science and application of light. 
The papers included in this volume were part of the technical conference cited on the cover and title page. Papers were selected and subject to review by the editors and conference program committee. Some conference presentations may not be available for publication. The papers published in these proceedings reflect the work and thoughts of the authors and are published herein as submitted. The publisher is not responsible for the validity of the information or for any outcomes resulting from reliance thereon.

Please use the following format to cite material from this book:

Author(s), "Title of Paper," in Coherence Domain Optical Methods and Optical Coherence Tomography in Biomedicine XII, edited by Joseph A. Izatt, James G. Fujimoto, Valery V. Tuchin, Proceedings of SPIE Vol. 6847 (SPIE, Bellingham, WA, 2008) Article CID Number.

ISSN 1605-7422

ISBN 9780819470225

Published by

SPIE

P.O. Box 10, Bellingham, Washington 98227-0010 USA

Telephone +1 3606763290 (Pacific Time) · Fax +1 3606471445

SPIE.org

Copyright (C) 2008, Society of Photo-Optical Instrumentation Engineers.

Copying of material in this book for internal or personal use, or for the internal or personal use of specific clients, beyond the fair use provisions granted by the U.S. Copyright Law is authorized by SPIE subject to payment of copying fees. The Transactional Reporting Service base fee for this volume is $\$ 18.00$ per article (or portion thereof), which should be paid directly to the Copyright Clearance Center (CCC), 222 Rosewood Drive, Danvers, MA 01923. Payment may also be made electronically through CCC Online at copyright.com. Other copying for republication, resale, advertising or promotion, or any form of systematic or multiple reproduction of any material in this book is prohibited except with permission in writing from the publisher. The CCC fee code is 1605 $7422 / 08 / \$ 18.00$.

Printed in the United States of America.

Publication of record for individual papers is online in the SPIE Digital Library.

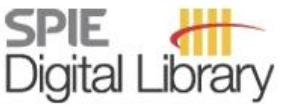

SPIEDigitallibrary.org

Paper Numbering: Proceedings of SPIE follow an e-First publication model, with papers published first online and then in print and on CD-ROM. Papers are published as they are submitted and meet publication criteria. A unique, consistent, permanent citation identifier (CID) number is assigned to each article at the time of the first publication. Utilization of CIDs allows articles to be fully citable as soon they are published online, and connects the same identifier to all online, print, and electronic versions of the publication. SPIE uses a six-digit CID article numbering system in which:

- The first four digits correspond to the SPIE volume number.

- The last two digits indicate publication order within the volume using a Base 36 numbering system employing both numerals and letters. These two-number sets start with 00, 01, 02, 03, 04 , $05,06,07,08,09,0 A, 0 B \ldots 0 Z$, followed by 10-1Z, 20-2Z, etc.

The CID number appears on each page of the manuscript. The complete citation is used on the first page, and an abbreviated version on subsequent pages. Numbers in the index correspond to the last two digits of the six-digit CID number. 


\title{
Contents
}

\author{
xi Conference Committee
}

xiii Introduction

\section{SESSION 1 OPHTHALMIC/DENTAL OCT}

684704 Keratometry and corneal topography using multiple delay element OCT [6847-03]

L. Plesea, A. Gh. Podoleanu, Univ. of Kent (United Kingdom)

684705 Segmentation of the retinal pigment epithelium by polarization sensitive optical coherence tomography [6847-04]

C. K. Hitzenberger, E. Götzinger, M. Pircher, B. Baumann, Medical Univ. of Vienna (Austria); S. Michels, W. Geitzenauer, U. Schmidt-Erfurth, General Hospital and Medical Univ. of Vienna (Austria)

684707 Fixed partial dentures investigated by optical coherent tomography [6847-06] C. Sinescu, M. Negrutiu, C. Todea, Victor Babeş Univ. of Medicine and Pharmacy of Timişoara (Romania); M. Hughes, F. Tudorache, A. Gh. Podoleanu, Univ. of Kent (United Kingdom)

\section{SESSION 2 CATHETER/ENDOSCOPIC OCT}

684708 In vivo endomicroscopy using three-dimensional optical coherence tomography and Fourier domain mode locked lasers [6847-07]

D. C. Adler, Y. Chen, Massachusetts Institute of Technology (USA); R. Huber, Massachusetts Institute of Technology (USA) and Ludwig-Maximilians-Univ. München (Germany); J. Schmitt, LightLab Imaging, Inc. (USA); J. Connolly, Beth Israel Deaconess Medical Ctr. (USA); J. G. Fujimoto, Massachusetts Institute of Technology (USA)

6847 OC Imaging fibre bundles for Fizeau-based optical coherence tomography [6847-11] G. F. Sarantavgas, H. D. Ford, R. P. Tatam, Cranfield Univ. (United Kingdom)

\section{SESSION 3 RETINAL FUNCTIONAL IMAGING}

6847 OG In vivo retinal blood flow measurement by Fourier domain Doppler optical coherence tomography [6847-15]

Y. Wang, O. Tan, D. Huang, Doheny Eye Institute and Keck School of Medicine, Univ. of Southern California (USA)

6847 ol Automatic retinal blood flow calculation using spectral domain optical coherence tomography [6847-17]

H. Wehbe, M. Ruggeri, S. Jiao, G. Gregori, C. A. Puliafito, Univ. of Miami Miller School of Medicine (USA) 
6847 0J Retinal blood flow measurement by using optical coherence tomography [6847-18] S. Makita, Univ. of Tsukuba (Japan); T. Fabritius, Univ. of Tsukuba (Japan) and Tokyo Medical Univ. (Japan); M. Miura, Univ. of Oulu (Finland) and Univ. of Tsukuba (Japan); T. Yatagai, Y. Yasuno, Univ. of Tsukuba (Japan)

\section{SESSION 4 FOURIER DOMAIN OCT: NEW TECHNOLOGY}

$6847 \mathrm{OM} \quad 60 \mathrm{MHz}$ A-line rate ultra-high speed Fourier-domain optical coherence tomography [6847-21]

K. Ohbayashi, D. Choi, H. Hiro-Oka, H. Furukawa, R. Yoshimura, M. Nakanishi, K. Shimizu, Kitasato Univ. (Japan)

6847 ON Linear wave-number spectrometer for spectral domain optical coherence tomography [6847-22]

G. V. Gelikonov, V. M. Gelikonov, P. A. Shilyagin, Institute of Applied Physics (Russia)

684700 Multi-channel Fourier domain OCT system with superior lateral resolution for biomedical applications [6847-23]

J. Holmes, S. Hattersley, Michelson Diagnostics Ltd. (United Kingdom); N. Stone,

F. Bazant-Hegemark, H. Barr, Gloucestershire Royal Hospital (United Kingdom)

6847 OR Narrowband wavelength selective detector applicable SD-OCT based on Fabry-Perot tunable filter and balanced photoreceiver [6847-26]

T. J. Eom, V. A. Tougbaev, B.-A. YU, W. Shin, Y. L. Lee, D.-K. Ko, Gwangju Institute of Science and Technology (South Korea); C.-S. Kim, E. J. Jung, J. S. Park, M. Y. Jeong, Pusan National Univ. (South Korea); E. S. Choi, Chosun Univ. (South Korea)

\section{SESSION 5 NOVEL TECHNIQUES}

6847 OS Miniature optical coherence tomography system based on silicon photonics [6847-27] E. Margallo-Balbás, Electronic Instrumentation Lab. (Netherlands); G. Pandraud, Kavli Institute of Nanoscience (Netherlands); P. J. French, Electronic Instrumentation Lab. (Netherlands)

$6847 \mathrm{OU}$ Investigations of $\mathrm{OCT}$ imaging performance using a unique source providing several spectral wavebands [6847-29]

R. Cernat, G. M. Dobre, I. Trifanov, L. Neagu, A. Bradu, M. Hughes, A. Gh. Podoleanu, Univ. of Kent (United Kingdom)

6847 OW Optical coherence tomography in material deformation by using short pulse laser irradiation [6847-31]

E. S. Choi, W. Kwak, Y. Shin, Chosun Univ. (South Korea); Y. Kim, Gwangju Institute of Science and Technology (South Korea); W. Jung, Y.-C. Ahn, Z. Chen, Univ. of California/Irvine (USA); E. J. Jeong, C.-S. Kim, Pusan National Univ. (South Korea)

6847 0X Dispersion-assisted measurement of the refractive index and thickness by hybrid interferometer [6847-32]

S. Kim, J. Na, M. J. Kim, B. H. Lee, Gwangju Institute of Science and Technology (South Korea) 
$68470 Z$ Programmable high speed ( 1MHz) Vernier-mode-locked frequency-swept laser for OCT imaging [6847-34]

M. Kourogi, Y. Kawamura, Optical Comb, Inc. (Japan); Y. Yasuno, Univ. of Tsukuba (Japan);

H. Oyaizu, H. Miyao, K. Imai, Optical Comb, Inc. (Japan)

684710 Spectrally balanced detection for OFDI [6847-35]

Y. Chen, D. M. de Bruin, C. Kerbage, J. F. de Boer, Harvard Medical School (USA) and

Wellman Ctr. for Photomedicine, Massachusetts General Hospital (USA)

684711 Large optical power margin of signal light in OFDR-OCT by using semiconductor optical amplifier [6847-36]

K. Asaka, NTT Corp. (Japan)

684712 High speed broadband Fourier domain mode locked swept source with multiple SOAs [6847-37]

J. Zhang, Beckman Laser Institute (USA) and Univ. of California, Irvine (USA); M. Y. Jeon,

Chung Nam National Univ. (South Korea); Z. Chen, Beckman Laser Institute (USA) and Univ. of California, Irvine (USA)

684713 Single-mode $140 \mathrm{~nm}$ swept light source realized by using SSG-DBR lasers [6847-38]

N. Fujiwara, R. Yoshimura, K. Kato, H. Ishii, F. Kano, Y. Kawaguchi, Y. Kondo, NTT Corp.

(Japan); K. Ohbayashi, Kitasato Univ. (Japan); H. Oohashi, NTT Corp. (Japan)

\section{SESSION 7 FULL-FIELD, PHASE, AND EXTENDED FOCUS IMAGING}

684717 Single-shot full-field OCT based on four quadrature phase-stepped interferometer [6847-43] M. S. Hrebesh, Y. Watanabe, Yamagata Univ. (Japan); R. Dabu, National Institute for Laser, Plasma and Radiation Physics (Romania); M. Sato, Yamagata Univ. (Japan)

684718 Dynamic focusing with radial gratings for in vivo high resolution imaging [6847-44]

L. Liu, N. Chen, National Univ. of Singapore (Singapore)

\section{SESSION $8 \quad$ NOVEL CONTRAST MECHANISMS}

684719 Spectral-domain magnetomotive OCT imaging of magnetic nanoparticle biodistribution [6847-45]

A. L. Oldenburg, V. Crecea, S. A. Rinne, R. Rezaeipoor, E. J. Chaney, Univ. of Illinois at Urbana-Champaign (USA); S. A. Boppart, Univ. of Illinois at Urbana-Champaign (USA) and Mills Breast Cancer Institute, Carle Foundation Hospital (USA)

6847 1A Fourier domain pump-probe optical coherence tomography: hemoglobin imaging at 830 $\mathrm{nm}$ [6847-46]

B. E. Applegate, D. Jacob, Texas A\&M Univ. (USA); J. A. Izatt, Duke Univ. (USA)

6847 1B Thermoelastic optical Doppler tomography of biological tissues [6847-47]

Q. Wang, Y.-C. Ahn, C. Kim, L. Yu, W. Jia, B. Rao, Z. Chen, Beckman Laser Institute (USA);

H. K. Chiang, Yang-Ming Univ. (Taiwan) 
6847 ID Visible-light OCT spectrometer for microvascular oximetry [6847-49]

S. V. Gangnus, S. J. Matcher, Univ. of Sheffield (United Kingdom)

6847 IE Quantifying permeability of glucose in normal and atherosclerotic pig aorta in vitro using optical coherence tomography [6847-50]

M. G. Ghosn, E. Carbajal, N. Befrui, Univ. of Houston (USA); V. V. Tuchin, Saratov State Univ. (Russia); K. V. Larin, Univ. of Houston (USA) and Saratov State Univ. (Russia)

\section{SESSION 9 DOPPLER AND POLARIZATION-SENSITIVE OCT}

$68471 \mathrm{~J}$ Polarization-sensitive swept-source optical coherence tomography with continuous polarization modulation [6847-55]

M. Yamanari, S. Makita, T. Yatagai, Y. Yasuno, Univ. of Tsukuba (Japan)

6847 IK Flow velocity analysis with joint spectral and time domain OCT [6847-56]

M. Szkulmowski, M. Wojtkowski, A. Szkulmowska, A. Kowalczyk, Nicolaus Copernicus Univ. (Poland)

6847 1M Simultaneous analysis of extinction and flow velocity with joint spectral and time domain OCT [6847-58]

M. Wojtkowski, M. Szkulmowski, T. Bajraszewski, A. Szkulmowska, A. Kowalczyk, Nicolaus

Copernicus Univ. (Poland)

\section{SESSION 10 FOURIER-DOMAIN OCT: IMAGE ENHANCEMENT}

6847 iN Simple technique for full-range complex spectral domain optical coherence tomography [6847-59]

B. Baumann, M. Pircher, E. Götzinger, C. K. Hitzenberger, Medical Univ. of Vienna (Austria)

6847 is Full range 1-um spectral domain optical coherence tomography by using electro-optical phase modulator [6847-64]

T. Fabritius, Univ. of Tsukuba (Japan) and Univ. of Oulu (Finland); S. Makita, M. Yamanari, Univ. of Tsukuba (Japan); R. Myllylä, Univ. of Oulu (Finland); T. Yatagai, Y. Yasuno, Univ. of Tsukuba (Japan)

\section{SESSION 11 IN VIVO IMAGING APPLICATIONS}

6847 IV In vivo imaging and vibration measurement of Guinea pig cochlea [6847-67]

N. Choudhury, F. Chen, J. Zheng, Oregon Health \& Science Univ. (USA); A. L. Nuttall, Oregon Health \& Science Univ. (USA) and Univ. of Michigan (USA); S. L. Jacques, Oregon Health \& Science Univ. (USA)

6847 IW Versatile confocal/optical coherence tomography system for embryonic developmental imaging [6847-68]

A. Bradu, L. Ma, J. Bloor, A. Podoleanu, Univ. of Kent (United Kingdom)

6847 IY Dynamic analysis of eccrin sweat glands on human fingertips by optical coherence tomography [6847-70]

M. Haruna, M. Ohmi, Y. Ueda, A. Yamada, H. Saigusa, Osaka Univ. (Japan) 
684721 Alignment of intravascular optical coherence tomography movies affected by nonuniform rotation distortion [6847-73]

G. van Soest, J. G. Bosch, Erasmus Univ. Medical Ctr. (Netherlands); A. F. W. van der Steen, Erasmus Univ. Medical Ctr. (Netherlands) and Interuniversity Cardiology Institute of The Netherlands (Netherlands)

684724 On the speckle size in optical coherence tomography [6847-76] G. Lamouche, C.-E. Bisaillon, S. Vergnole, J. P. Monchalin, National Research Council Canada (Canada)

684725 Local variations in bone mineral density: a comparison of OCT versus x-ray micro-CT [6847-77]

N. Ugryumova, J. Stevens-Smith, A. Scutt, S. J. Matcher, Univ. of Sheffield (United Kingdom)

684726 Gouy phase shift in Fourier-domain optical coherence tomography [6847-78]

G. Lamouche, S. Vergnole, M. L. Dufour, B. Gauthier, National Research Council Canada (Canada)

\section{POSTER SESSION}

6847 2A Numerical method for compensating the retinal shadows of optical coherence tomography images [6847-81]

T. Fabritius, Univ. of Tsukuba (Japan) and Univ. of Oulu (Finland); S. Makita, Univ. of Tsukuba (Japan); Y. Hong, Korea Advanced Institute of Science and Technology (South Korea); R. Myllylä, Univ. of Oulu (Finland); T. Yatagai, Y. Yasuno, Univ. of Tsukuba (Japan)

$68472 \mathrm{~B} \quad$ Speckle reduction method for optical coherence tomography using interval type II fuzzy set [6847-82]

P. Puvanathasan, K. Bizheva, Univ. of Waterloo (Canada)

$68472 \mathrm{C}$ Use of cosine tapered window to improve dynamic range of OCT without loss of resolution [6847-83]

H. Hiro-Oka, D. Choi, H. Furukawa, R. Yoshimura, K. Ohbayashi, Kitasato Univ. (Japan);

T. Wakabayashi, Teikyo Univ. (Japan)

6847 2D Spectral density and tissue perfusion from speckle contrast measurements [6847-84]

O. B. Thompson, M. K. Andrews, Industrial Research Ltd. (New Zealand)

$68472 \mathrm{~F} \quad$ Side-imaging lensed photonic crystal fiber probe [6847-86]

H. Y. Choi, S. Y. Ryu, J. Na, B. H. Lee, I.-B. Sohn, Y.-C. Noh, J. Lee, Gwangju Institute of Science and Technology (South Korea)

$68472 \mathrm{G}$ Doppler optical coherence tomography measurements in discretely swept optical frequency domain imaging [6847-87]

R. Yoshimura, H. Hiro-Oka, D. Choi, H. Furukawa, Kitasato Univ. (Japan); N. Fujiwara, NTT

Corp. (Japan); K. Ohbayashi, Kitasato Univ. (Japan) 
$68472 \mathrm{~K}$ Axial-lateral parallel time domain OCT with an optical zoom lens and high order diffracted lights at $830 \mathrm{~nm}$ [6847-92]

Y. Watanabe, Y. Takasugi, M. Sato, Yamagata Univ. (Japan)

$68472 \mathrm{~L} \quad$ All-fiber probe for optical coherence tomography [6847-93]

S. Y. Ryu, H. Y. Choi, J. Na, W. J. Choi, B. H. Lee, Gwangju Institute of Science and Technology (South Korea)

$68472 \mathrm{M}$ Spectral domain optical coherence tomography using a microchip laser-pumped photonic crystal fiber supercontinuum source [6847-94]

Q. Zhao, T. Buma, Univ. of Delaware (USA)

$68472 \mathrm{~N}$ Broadband superluminescent light-emitting device at $840 \mathrm{~nm}$ with high performance stability [6847-95]

V. Laino, L. Occhi, P. Navaretti, C. Velez, EXALOS AG (Switzerland)

684720 Measurement of sinusoidal flow oscillations in a glass capillary tube using phase-resolved DOCT [6847-96]

C. Blake, J. Edmunds, L. Shelford, J. Moger, Univ. of Exeter (United Kingdom); S. J. Matcher, Univ. of Sheffield (United Kingdom)

6847 2P SGDBR single-chip wavelength tunable lasers for swept source OCT [6847-97]

D. Derickson, M. Bernacil, A. DeKelaita, B. Maher, S. O'Connor, California Polytechnic State Univ. (USA); M. N. Sysak, L. Johanssen, Univ. of California/Santa Barbara (USA)

$68472 \mathrm{Q}$ Measurement of the three-dimensional point-spread function in an optical coherence tomography imaging system [6847-98]

P. H. Tomlins, P. Woolliams, M. Tedaldi, A. Beaumont, C. Hart, National Physical Lab. (United Kingdom)

$68472 R \quad$ Real-time video-rate harmonically detected Fourier domain optical coherence tomography [6847-99]

A. B. Vakhtin, K. A. Peterson, D. J. Kane, Southwest Sciences, Inc. (USA)

684725 Optimal source bandwidth for pass-through photon-based trans-illumination interferometry [6847-100]

P. Vacas-Jacques, M. Strojnik, G. Paez, Ctr. de Investigaciones en Óptica (Mexico)

6847 2T Enhancement of Fourier domain optical coherence tomography images using discrete Fourier transform method [6847-101]

T. H. Chow, S. Gulam Razul, B. K. Ng, Nanyang Technological Univ. (Singapore); G. Ho, Institute of Bioengineering and Nanotechnology (Singapore); C. B. A. Yeo, Nanyang Technological Univ. (Singapore)

$68472 \mathrm{~V}$ Penetration depth of optical frequency domain imaging at wavelengths of $1310 \mathrm{~nm}$ and $1550 \mathrm{~nm}$ [6847-103]

H. Furukawa, D. Choi, H. Hiro-Oka, R. Yoshimura, M. Nakanishi, K. Shimizu, K. Ohbayashi, Kitasato Univ. (Japan) 
6847 2W Common path swept-source OCT interferometer with artifact removal [6847-104] S. Vergnole, G. Lamouche, M. L. Dufour, B. Gauthier, National Research Council Canada (Canada)

6847 2Y In vivo 3-D imaging of gastrointestinal tracts by use of an endoscopic swept source optical coherence tomography with a microelectromechanical endoscopic rotational probe [6847-106]

J. Zhang, J. SU, Beckman Laser Institute (USA) and Ctr. for Biomedical Engineering, Univ. of California, Irvine (USA); K. Chang, Univ. of California Irvine Medical Ctr. (USA);

Z. Chen, Beckman Laser Institute (USA) and Ctr. for Biomedical Engineering, Univ. of California, Irvine (USA)

684730 In vitro 3D articular cartilage imaging using endoscopic spectral domain optical coherence tomography (SD-OCT) with a GRIN (gradient index) lens rod based probe [6847-108]

T. Xie, Y. Ahn, Z. Chen, G. Peavy, Beckman Laser Institute (USA)

684731 Spectrometer based Fourier domain optical coherence tomography of the mouse retina [6847-109]

J. Xu, M. H. Khorasani, J. N. B. Koo, M. V. Sarunic, Simon Fraser Univ. (Canada)

684732 Imaging treated brain aneurysms in vivo using optical coherence tomography [6847-1 10] J. SU, Univ. of California, Irvine (USA) and Beckman Laser Institute and Medical Clinic (USA); M. S. Mathews, Beckman Laser Institute and Medical Clinic (USA) and Univ. of California, Irvine (USA); C. I. Nwagwu, A. Edris, B. V. Nguyen, M. Heidari, M. E. Linskey, Univ. of California, Irvine (USA); Z. Chen, Univ. of California, Irvine (USA) and Beckman Laser Institute and Medical Clinic (USA)

Author Index 
Downloaded From: https://www.spiedigitallibrary.org/conference-proceedings-of-spie on 26 Apr 2023

Terms of Use: https://www.spiedigitallibrary.org/terms-of-use 


\title{
Conference Committee
}

\author{
Symposium Chairs \\ James G. Fujimoto, Massachusetts Institute of Technology (USA) \\ R. Rox Anderson, Wellman Center for Photomedicine, Massachusetts \\ General Hospital (USA) and Harvard School of Medicine (USA)
}

Program Track Chairs

Tuan Vo-Dinh, Duke University (USA)

Anita Mahadevan-Jansen, Vanderbilt University (USA)

\section{Conference Chairs}

Joseph A. Izatt, Duke University (USA)

James G. Fujimoto, Massachusetts Institute of Technology (USA)

Valery V. Tuchin, Saratov State University (Russia)

Program Committee

Peter Eskil Andersen, Danmarks Tekniske Universiteit (Denmark)

Stephen A. Boppart, University of Illinois at Urbana-Champaign (USA) and Mills Breast Cancer Institute, Carle Foundation Hospital (USA)

Zhongping Chen, Beckman Laser Institute (USA)

Johannes F. de Boer, Wellman Center for Photomedicine, Massachusetts General Hospital (USA) and Harvard School of Medicine (USA)

Wolfgang Drexler, Cardiff University (United Kingdom)

Christoph K. Hitzenberger, Medizinische Universität Wien (Austria)

Rainer Andreas Leitgeb, École Polytechnique Fédérale de Lausanne (Switzerland)

Xingde Li, University of Washington (USA)

Adrian Gh. Podoleanu, University of Kent (United Kingdom)

Andrew M. Rollins, Case Western Reserve University (USA)

Natalia Mihilovna Shakhova, Institute of Applied Physics (Russia)

Guillermo J. Tearney, Massachusetts General Hospital (USA)

Ruikang K. Wang, Oregon Health and Science University (USA)

Maciej Wojtkowski, Nicolaus Copernicus University (Poland) 
Session Chairs

1 Ophthalmic/Dental OCT

Joseph A. Izatt, Duke University (USA)

2 Catheter/Endoscopic OCT

James G. Fujimoto, Massachusetts Institute of Technology (USA)

3 Retinal Functional Imaging

Johannes F. de Boer, Wellman Center for Photomedicine,

Massachusetts General Hospital (USA) and Harvard School of Medicine (USA)

$4 \quad$ Fourier Domain OCT: New Technology

Maciej Wojtkowski, Nicolaus Copernicus University (Poland)

$5 \quad$ Novel Techniques

Xingde Li, University of Washington (USA)

6 Fourier Domain Swept Source OCT

Zhongping Chen, Beckman Laser Institute (USA)

$7 \quad$ Full-Field, Phase, and Extended Focus Imaging

Rainer Andreas Leitgeb, École Polytechnique Fédérale de Lausanne (Switzerland)

8 Novel Contrast Mechanisms

Stephen A. Boppart, University of Illinois at Urbana-Champaign (USA) and Mills Breast Cancer Institute, Carle Foundation Hospital (USA)

9 Doppler and Polarization-Sensitive OCT

Christoph K. Hitzenberger, Medizinische Universität Wien (Austria)

10 Fourier-Domain OCT: Image Enhancement

Wolfgang Drexler, Cardiff University (United Kingdom)

11 In Vivo Imaging Applications

Peter Eskil Andersen, Danmarks Tekniske Universiteit (Denmark)

12 OCT Signal and Image Processing

Valery V. Tuchin, Saratov State University (Russia) 


\section{Introduction}

These proceedings are from the Coherence Domain Optical Methods and Optical Coherence Tomography in Biomedicine XII Conference, held January 2123, 2008 at the SPIE Photonics West Symposium in San Jose, California. This year's conference featured 111 oral and poster presentations from leading national and international research groups.

The conference was organized into several sessions including: Fourier Domain OCT: New Technology; Fourier Domain Swept Source OCT; Fourier-Domain OCT: Image Enhancement; Full-Field, Phase, and Extended Focus Imaging; Doppler and Polarization-Sensitive OCT; Novel Techniques; Novel Contrast Mechanisms; OCT Signal and Image Processing; Catheter/Endoscopic OCT; Ophthalmic/Dental OCT; Retinal Functional Imaging; In Vivo Imaging Applications; and a poster session with 32 presentations. As usual, a predominant fraction of the papers focused on optical coherence tomography - basic research, instrumentation, and applications.

This year, there were significant advances in Fourier Domain OCT Imaging (three sessions, New Technology, Swept Source OCT, and Image Enhancement, with 20 oral and six poster presentations) with discussion of $60 \mathrm{MHz}$ A-line rate ultra-high speed FD OCT, multi-channel system with superior lateral resolution, K-space linear Fourier domain and programmable high-speed $(\sim 1 \mathrm{MHz})$ Vernier modelocked frequency-swept lasers, single-mode $140 \mathrm{~nm}$ swept light source realized by using SSG-DBR lasers, as well as techniques for full-range complex spectral domain OCT.

Extended focus Fourier domain optical coherence microscopy and fluorescence lifetime imaging, dispersion free low coherence interferometry, depth-encoded spectral domain phase microscopy for simultaneous multi-site nanoscale displacement measurements, real-time high-resolution optical coherence microscopy with binary-phase spatial filters, single-shot full-field OCT based on four quadrature phase-stepped interferometer, and dynamic focusing OCT with radial gratings for in vivo high-resolution imaging were presented and discussed in six papers in the session on Full-Field, Phase, and Extended Focus Imaging.

Six oral presentations in the session on Doppler and Polarization-Sensitive OCT reported advanced technologies for in vivo quantification of volumetric cerebrovascular blood perfusion in mice through intact skin by optical microangiography, for enhanced performance in phase-resolved Doppler OCT, for flow velocity analysis and calibration. New approaches in polarization-sensitive OCT, such as polarization-sensitive swept-source OCT with continuous polarization modulation, were also discussed in this and the poster session. 
The session on Novel Techniques contained six oral papers and was devoted to further development of OCT components and whole systems, such as a miniature OCT system based on silicon photonics, Fourier domain low coherence transillumination computed tomography, OCT systems based on unique source providing several spectral wavebands, superconducting single-photon detectors, and hybrid interferometer.

The Novel Contrast Mechanisms session contained eight oral presentations and discussed OCT imaging of distribution of magnetic nanoparticles, pump-probe OCT for hemoglobin imaging at $830 \mathrm{~nm}$, measurement of the hemoglobin oxygen saturation and microvascular oximetry, thermoelastic optical Doppler tomography of tissues, quantifying permeability of glucose in skin in vivo, motility contrast imaging of tumor response to anti-mitotic cancer drugs, and usage of gold nanoshells for increasing contrast and functional information in OCT imaging.

Various OCT processing modalities were discussed in eight papers in the session on OCT Signal and Image Processing, including clustering of spectroscopic OCT images for contrast enhancement, segmentation, and diagnosis, automated calculation of fiber orientation from 3-D cardiac OCT volumes, alignment of intravascular OCT movies affected by non-uniform rotation distortion, denoising of OCT images, real-time signal processing using field programmable gate arrays, speckle size quantification, a comparison of OCT versus x-ray micro CT, and defining of Gouy phase shift in FD OCT.

The Catheter/Endoscopic OCT session contained six papers and discussed recent achievements in in vivo OCT endomicroscopy, 3-D comprehensive microscopy and design of balloon catheter optics for OCT imaging of the human esophagus, catheter-based high-speed polarization sensitive frequency domain imaging, design of imaging fiber bundles for Fizeau based OCT, and subsurface and Doppler spectrally encoded endoscopy.

Three sessions, Ophthalmic/Dental OCT, Retinal Functional Imaging, and In Vivo Imaging Applications, with 18 papers were devoted to biomedical studies using various OCT technologies. These studies included in vivo high-speed OCT and motion corrected simultaneous SLO/OCT imaging of the human retina, keratometry and cornea topography, segmentation of the retinal pigment epithelium by PS OCT, modeling of light scattering from retinal photoreceptors and their in vivo optical probing. A few papers presented advanced researches of human retinal blood flow. One paper described non-invasive optical detection of functionally stimulated neural activity in the limulus compound eye. Two papers were devoted to embryonic developmental imaging, including a highthroughput longitudinal imaging of the embryonic heart. One paper has shown an in vivo imaging and vibration measurement of guinea pig cochlea. Real-time OCT for the intraoperative microscopic assessment of surgical margins in breast cancer and successful monitoring of the evolution of oral cancerous tissue were 
also demonstrated. Dynamic analysis of eccrine sweat glands of human fingertips was also presented in this session.

The poster session contained 32 papers on the major above-mentioned topics.

A short course for engineers, scientists, and clinicians, SC312 - Principles and Applications of Optical Coherence Tomography by James Fujimoto, accompanied the conference.

All submissions were fully peer reviewed. Authors were requested to submit a three-page summary of their paper. The program committee evaluated the submissions for technical content and assigned a numerical score to each paper. The selection of the papers as oral presentations, posters, or non-acceptance was based upon the program committee score. Although this process was time consuming, we felt that it was important for the conference. Many participants felt that the technical quality and novelty of the papers had increased as the result of peer review. The peer review also provided a fairer assessment of the submitted papers. We have had very positive feedback and a record number of submissions and attendees (see photo) this year.

The conference chairs would like to thank the members of the technical program committee for their help in organizing the conference. We sincerely appreciate the support of SPIE and the conference staff. Finally, we would like to thank all of the conference attendees and manuscript authors for their contributions and participation that helped to make this meeting a success.

\section{Joseph A. Izatt \\ James G. Fujimoto \\ Valery V. Tuchin}


Downloaded From: https://www.spiedigitallibrary.org/conference-proceedings-of-spie on 26 Apr 2023

Terms of Use: https://www.spiedigitallibrary.org/terms-of-use 